\title{
The Fortication of lodine in Salt Consumption Using Manual Gun Spray
}

\author{
Intan Baroroh ${ }^{1, *}$, Bagiyo Suwasono ${ }^{2}$, Didik Hardianto ${ }^{2}$ \\ ${ }^{1}$ Department of Naval Architecture, Faculty of Engineering and Marine Science, Hang Tuah \\ University, Indonesia \\ ${ }^{2}$ Department of Naval Architecture, Faculty of Engineering and Marine Science, Hang Tuah \\ University, Indonesia
}

\begin{abstract}
The Blue Economy concept begins with Artemia salt farming. The salt farming industry is one of the pillars supporting the economic of coastal community. However, in the market, most of salt consumed have iodine level that is less than $30 \mathrm{ppm}$. Therefore, it is necessary to measure the supply of iodized salt from the market to reach $30-80 \mathrm{ppm}$ iodium according to Indonesia National Standard because it can impact our health. Thus, it was necessary to repair the iodized salt production equipment through an iodine spray device on the machine. The result of spray setting modification technology on macro ranged from 38 - 45 ppm which fulfilled Indonesia National Standard.
\end{abstract}

\section{Introduction}

The Blue Economy concept becomes the new trending topic for the government to explore the economical potency in oceanography and fishery in Indonesia developed to enhance the role of private parties in pro-environment economics development through business and innovative investment, and basically, there are five basic purposes to achieve; natural resources efficiency, zero waste, social inclusiveness, cyclic systems of production: endless generation to regeneration, balancing production and consumption, and Openended innovation and adaptation. This economics perspective is suitable with the program of poverty reduction (pro-poor), pro-growth, pro-jobless, and pro-environment. Thus, those five basic development, started with the Artemia salt farming become the milestone of the coastal economic community support. The distribution of the iodized salt from the company to the market or society depends on the production competency and marketing effort in free-trade era. The isolated areas with traditional markets will not be reached by the suppliers of iodized salt because of its few access. Thus, traditional markets mostly are supplied with non-iodized salt that encouraged people to fake the content of iodine. The conducted surveys showed that many packages of salt are claimed to have iodine in it, but the content of KIO is less than $30 \mathrm{ppm}$ as the standard applied.

\footnotetext{
* Corresponding author : intan.baroroh@hangtuah.ac.id
} 
Based on a research [1] showed that there were 6 out of 10 types of salt sold in the markets in Bogor just contained iodine that were less than $40 \mathrm{ppm}$ [2]. In food processing, based on a research done [3], using the food processor, the volume of the iodine added was less than the volume of the salt, so the distribution of the iodine was not spread well. Meanwhile, at Sunan Drajat Research Centre, the iodized salt machine is still far from the standardized one that is less than $30 \mathrm{ppm}$. Thus, it is very crucial to invent a device or technology, efficient and accurate, that meets the needs: the supply of iodized salt with the range of 30-80 ppm. The modified iodized salt spray machine will enhance salt farmers' productivity in the number of salt produced and its quality: iodized salt with the range of 30-80 ppm.

Some impact of iodized salt are very crucial for family health such as triggering the brain growth, making thyroid glands and fetus growth healthy, and the lack in consuming will lead to swollen thyroid glands, mental retardation, defected born baby, children with low smartness, miscarriage, etc. The excessive consumption will lead to hyper-thyroids, a condition when thyroid glands are produced excessively, and it forms goiter. In fact, goiter is also formed when thyroid glands are inactive, too. Moreover, sour taste emerges on the mouth and the saliva is produced excessively, and iodine also irritates the digestive systems by bruising it.

The usage of the gun spray on iodized salt device in the fulfilment of salt consumption for the salt farmers at Paciran, Lamongan will be illegible for the lab test, selling purposes, and people consumption, as the continuity of further purification process.

\subsection{Working Principles of Manual Gun Spray to the Machine of lodized Process for Soft Salt}

The iodized device located at Sunan Drajat was still in defect stage since there was the iodine spraying process could not be done continually on the soft salt that results the changes of ppm, 25-50 ppm. Thus, it had to be repaired. Its modification was in the usage of manual gun spray using the energy of compressor for the first treatment done.

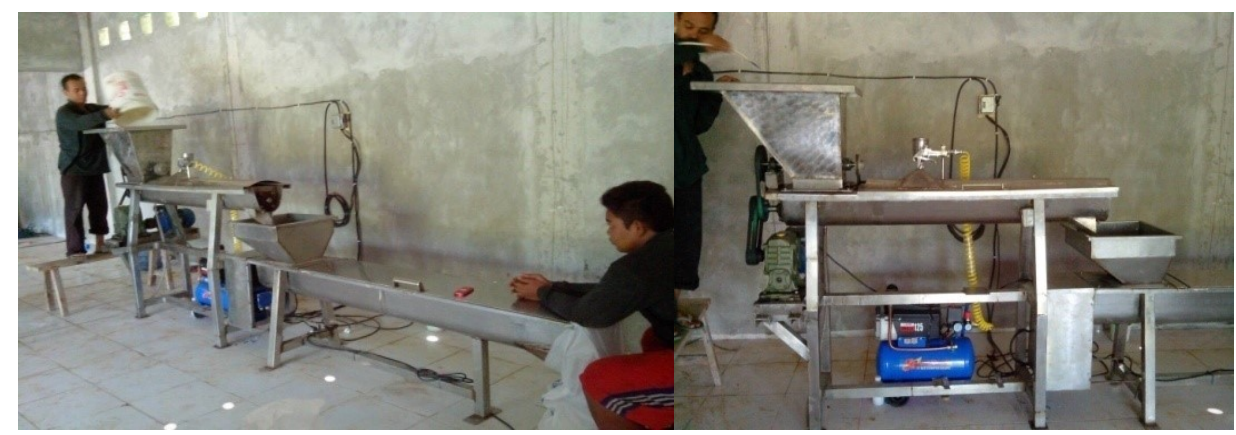

Fig. 1. The Existence of Iodized Machine.

The compressor was linked to the manual gun spray to fill the air from the compressor to the spray to make iodized clouds. The air from the compressor entered the spray by pushing the handle, and it was done continually. The air hose was so small, $3 \mathrm{~mm}$ in diameter, so it was easy to block because it was used by pushing it many times. At present, the iodized machine with its spray had already being attached and used at Raw Salt Processing Unit, Sunan Drajat, Lamongan to elevate the capacity and the quality of the product called Garam Samudra, shown on Picture 1: Iodized Machine. The mechanism was the soft salt with $\mathrm{NaCl}$ more than $97 \%$ content was put to the iodized machine regularly to filter the salt to the screw impeller bucket, and the machine was used to mix and spread iodine to the softened 
salt. Iodized salt product was produced using a machine with 2 types of parts: belt and screw conveyors within 2 stages. The first stage was putting the raw salt to the feeder, and then move upward through belt conveyor. At last, the final cycle was the iodine spraying process. At the second stage, iodized salt was moved from the belt conveyor to the screw conveyor that move upward to enter the container bucket. The weakness was stability and homogeneity of KIO3 content in its each product. Iodized salt consumption must meet the standard, SNI 3556-2010 that has the content of $\mathrm{NaCl}>94 \%$ and the content of $\mathrm{KIO} 3>30$ $\mathrm{ppm}$. Thus, the successful indicator of iodized soft salt fortification machine build-up was the achievement on the homogeneity level and the level of KIO3 that ranges between 30 to $80 \mathrm{ppm}$. The situation of iodized machine testing using brush water spray and compressor.

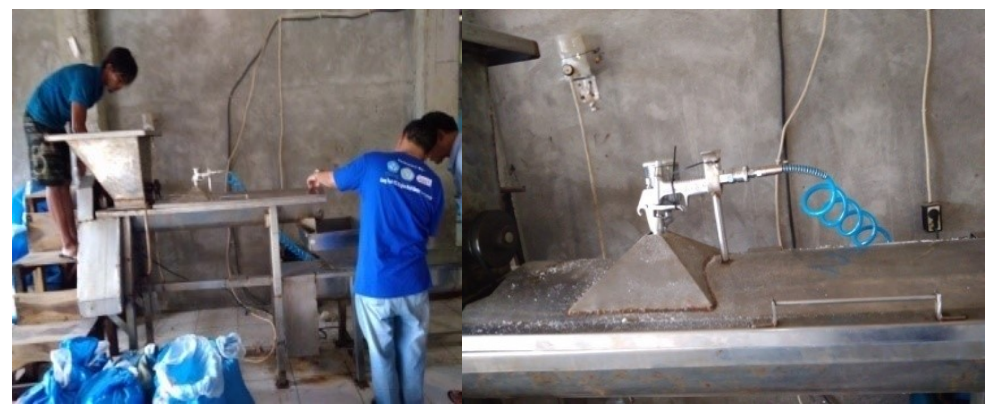

Fig. 2. The testing of brush water spray using a compressor. (left)

Fig. 3. The position of the brush water spray that was put into the screw of iodized machine (right)

\section{Research Method}

This research used a machine that applied two times of treatments on iodine by spraying iodized liquid through the nozzle spray to the device. The spray was intended to make iodized component (KIO3) that reached 30-80 ppm that becomes the standard of iodine consumption in Indonesia.

In the first measurement, it used spray nozzle with compressor power to spray iodine liquid to the smooth salt with the combination of 6 gram of iodine that was added by $120 \mathrm{cc}$ of fresh water. Each trial needed $120 \mathrm{~kg}$ for five times, so the total weight was 600 kilograms.

In the second measurement, it used spray nozzle with compressor power to spray iodine liquid to the smooth salt with the combination of 6 gram of iodine that was added by $120 \mathrm{cc}$ of fresh water. Each trial needed $100 \mathrm{~kg}$ for five times, so the total weight was 500 kilograms.

Both procedures above used the nozzle spray with a compressor power that was intended to make the salt smooth and homogeneous. Thus, the second procedure would make the result smoother than the first result and more homogeneous. At last, the resulted iodized salt would reach $30-80 \mathrm{ppm}$ of consumptive salt.

Based on both final results, there were 30 salt samples that were tested using KIO3 at laboratory owned by Surabaya Airlangga University. Each step of the testing, it needed 120 kilograms of smooth salt that was applied within five times of stages, and $100 \mathrm{~kg}$ that also was applied within five times of stages. Thus, there were approximately 1,1 tons of smooth salt needed. If the process did not produce iodine component less than $30 \mathrm{ppm}$, the process was repeated from the rotary drying by mixing the smooth salt with iodized liquid concentrate based on its measurement until the sample showed the standardized iodine level. The flow chart of the research methodology can be seen at below. 


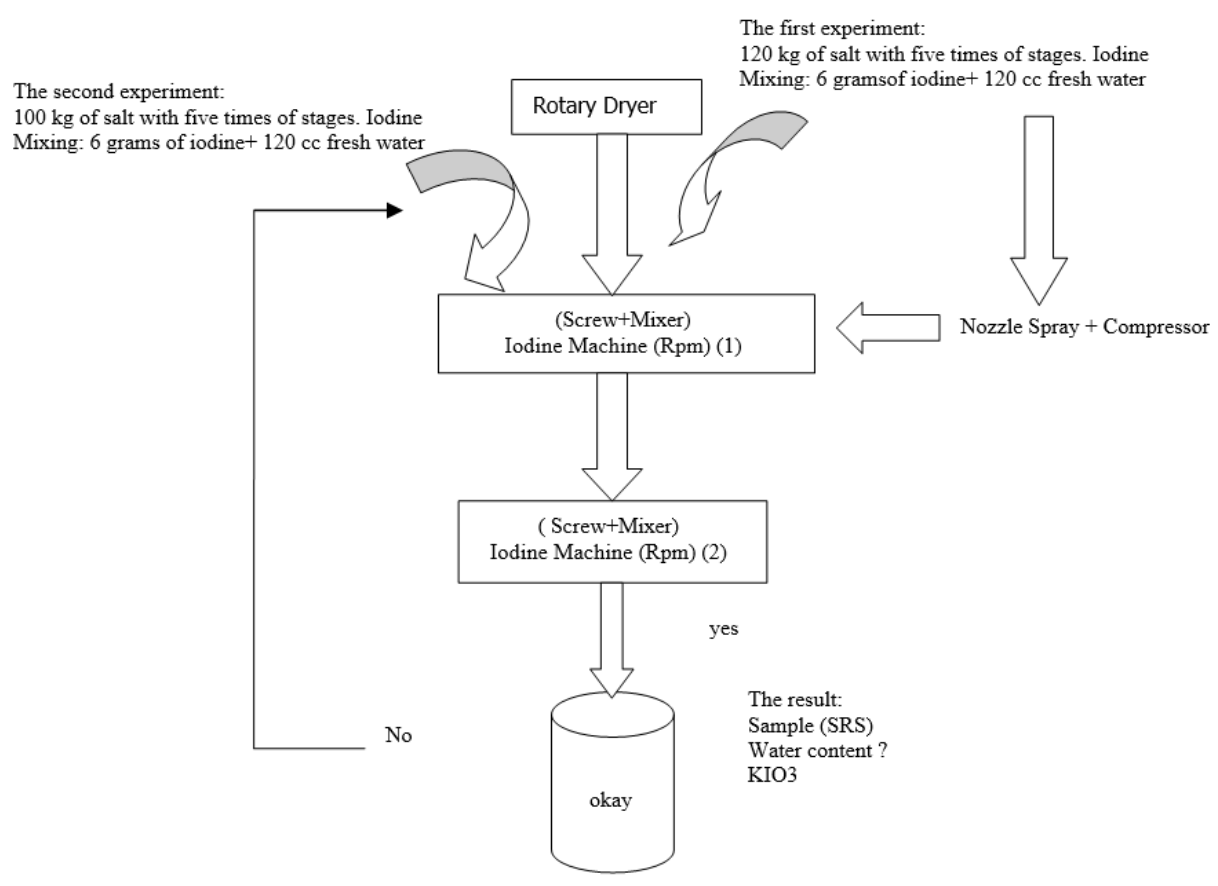

Fig. 4. The flow chart of research method of modified iodized spray machine.

\subsection{The Indicator of Applied Research}

The indicator of the research was 30 samples of KIO3 ranged from $30-80$ ppm with water component less than $7 \%$, and the adjusted compressor pressure on the device. The expected final results were:

1. The whiteness of the salt was more than $4.7 \%$

2. KIO3 component of the salt was $30-80 \mathrm{ppm}$

3. The content of the water was less than $7 \%$.

4. KIO3 homogeny in each gram of produced salt.

\subsection{The early study of iodized "Garam Samudra"}

It needed a certain portion of iodized salt for the consumption that it ranged from $30-80$ ppm that were spread well.

\section{3 lodized Spray Modification}

Having the previous result, the modification was to measure the composition of iodine input and water to the salt to reach 30-80 ppm. The application of KIO3 $(\mathrm{mg} / \mathrm{kg}) 30-80$ ppm that was added by water $<7 \%$, using the balance of its pressure (Psi/bar)on the nozzle spray to the spinning of mixed salt (Rpm).

\subsection{Chemical Lab Testing on Salt Consumption Product.}

All samples taken were planned to have 32 samples using chemical lab testing to find out whether the salt final product met Indonesian Standard which is $\mathrm{NaCl}>94,7 \%, \mathrm{KIO} 3 \&$ 
$(\mathrm{mg} / \mathrm{kg}) 30-80 \mathrm{ppm}$, water content $<7 \%$ and its homogeny.

\section{Result and Discussion}

The research was conducted at Sunan Drajat, Lamongan, Banjarwati Village, Paciran Subdistrict, Lamongan. The machine applied there, in the process of fortification, showed unstable continuity of iodine spraying, so the spread of iodine content changes in the range of 25-50 ppm, so the repair on that machine was conducted using manual gun spray with the support of compressor energy.

The trial on the iodized machine capacity to reach the speed and the result of the production was undergone 5 times. The measurement of the input of the soft salt and its output was the decreased amount of the output salt that can be seen in the following table.

Table 1. Iodized Machine Capacity-testing.

\begin{tabular}{|c|c|c|c|c|}
\hline No & $\begin{array}{c}\text { Input } \\
(\mathbf{k g})\end{array}$ & $\begin{array}{c}\text { Output } \\
(\mathbf{k g})\end{array}$ & $\begin{array}{c}\text { The loss } \\
(\mathbf{k g})\end{array}$ & $\begin{array}{c}\text { Time } \\
(\text { minutes })\end{array}$ \\
\hline 1 & 112,88 & 106,64 & 6,24 & 5,4 \\
\hline 2 & 114,55 & 116,32 & $-1,77$ & 8,2 \\
\hline 3 & 116,32 & 109,04 & 7,28 & 8,14 \\
\hline 4 & 111,09 & 111,44 & $-0,35$ & 8,15 \\
\hline 5 & 111,44 & 110,59 & 0,85 & 8,08 \\
\hline Amount & 566,28 & 554,03 & 12,25 & 37,97 \\
\hline Average & 113,256 & 110,806 & 2,45 & 7,594 \\
\hline
\end{tabular}

The result of the iodized salt machine was if the input was $113,256 \mathrm{~kg}$, the output was $110,806 \mathrm{~kg}$, so it could be concluded that there was $2.45 \mathrm{~kg}$ of loss. The speed in the fortification process was $14.7 \mathrm{~kg} /$ minute, and its product capacity was $882 \mathrm{~kg} / \mathrm{hour}$.

For the trial of the device, manual gun spray and a compressor were used, and the spray of iodized liquid was applied by combining 6 grams of iodine that was added by 120 cc of plain water. Then, it was sprayed on soft salt of $120 \mathrm{~kg}$ for 5 times, so the total number of salt tested was $600 \mathrm{~kg}$ for the first trial. However, the second trial used the spray and compressor with 6 grams of iodine that was added by $120 \mathrm{cc}$ of fresh water was the spraying to the soft salt, weighing 100 kilograms for five times, so the total amount of salt was 500 kilograms. Thus, the total number of soft salt used in this manual gun spray testing using compressor energy was 1100 kilograms.

\subsection{The Testing Result of Manual Gun Spray Usage on lodized Process of Soft Salt}

The result of iodized-testing on the iodized machine was the sample result (conducted at Airlangga University lab) that has iodine content using spray and compressor as follows: 
Table 2. Batch 1. Salt: $120 \mathrm{~kg}$, iodine: $6 \mathrm{gr}$, and water: $120 \mathrm{cc}$

\begin{tabular}{|r|c|c|c|c|c|c|c|}
\hline No & Batch 1 & Iodine -1 & Iodine -2 & Iodine -3 & Total & Mean & $\begin{array}{c}\text { Deviation } \\
\text { Std. }\end{array}$ \\
\hline 1 & C1 & 12,47 & 10,12 & 9,41 & 32 & 10,66 & 1,60157 \\
\hline 2 & C2 & 60,84 & 60,29 & 61,91 & 183,04 & 61,01 & 0,82379 \\
\hline 3 & C 3 & 74,12 & 74,19 & 75,61 & 223,92 & 74,64 & 0,84077 \\
\hline 4 & C4 & 17,88 & 14,77 & 14,64 & 47,29 & 15,76 & 1,83424 \\
\hline 5 & C5 & 32,86 & 31,44 & 29,73 & 94,03 & 31,34 & 1,56724 \\
\hline & Total & 198,17 & 190,81 & 191,30 & & & \\
\hline & Mean & 39,6340 & 38,1620 & 38,2600 & & & \\
\hline & $\begin{array}{c}\text { Deviation } \\
\text { Standard }\end{array}$ & 26,90718 & 28,13534 & 29,22898 & & & \\
\hline
\end{tabular}

Table 3. Batch 2. Salt: $100 \mathrm{~kg}$, iodine: 6 gr and water: $120 \mathrm{cc}$.

\begin{tabular}{|c|c|c|c|c|c|c|c|}
\hline No & Batch 2 & Iodine -1 & Iodine -2 & Iodine $\mathbf{- 3}$ & Total & Mean & $\begin{array}{l}\text { Deviation } \\
\text { Std. }\end{array}$ \\
\hline 6 & C6 & 85,59 & 85,27 & 86,21 & 257,07 & 85,69 & 0,47791 \\
\hline 7 & C7 & 42,39 & 42,25 & 42,08 & 126,72 & 42,24 & 0,15524 \\
\hline 8 & $\mathrm{C} 8$ & 52,46 & 52,54 & 52,66 & 157,66 & 52,55 & 0,10066 \\
\hline 9 & C9 & 23,23 & 22,88 & 22,46 & 68,57 & 22,85 & 0,38553 \\
\hline 10 & $\mathrm{C} 10$ & 23,67 & 20,84 & 20,42 & 64,93 & 21,64 & 1,76766 \\
\hline & Total & 227,34 & 223,78 & 223,83 & & & \\
\hline & Mean & 45,4680 & 44,7560 & 44,7660 & & & \\
\hline & $\begin{array}{l}\text { Deviation } \\
\text { Standard }\end{array}$ & 25,67985 & 26,26209 & 26,82080 & & & \\
\hline
\end{tabular}

Production Target:

Indonesian Standard $3556: 2010$

Salt crystal $\quad>94 \%$

Iodine KIO3 $>30 \mathrm{ppm}$

Water $(\mathrm{H} 2 \mathrm{O})<7 \%$.

The Result of the National Standardized Salt was seen in the picture below.

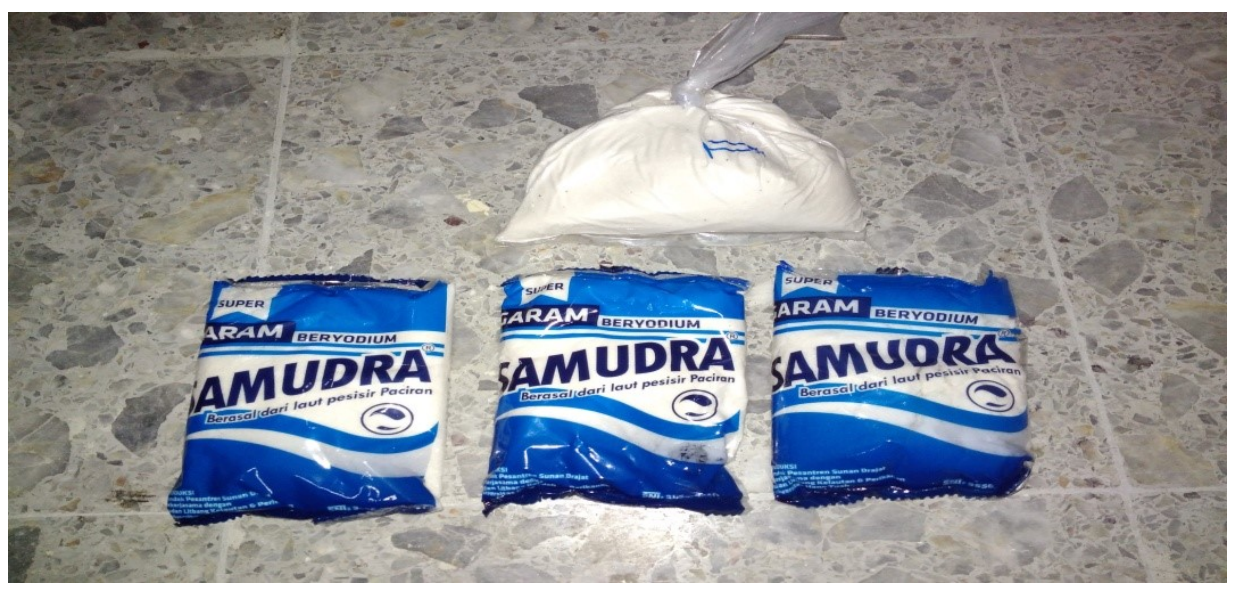

Fig. 5. The Result of the Production of Samudra Salt at Islamic boarding school of Sunan Drajat, Lamongan 
From the result of spray setting, it worked well on the second process; the preliminary and the final settings had a significant influence. The focus would be the pressure setting on the compressor with bar/Psi on the compressor. Moreover, nozzle setting was its height on the spinning of iodized machine screw that had to be reset because the hole was interrupted by its spinning in the iodine mixing process. Thus, the result of first testing result, Po (output) had to be put as the input, and the Pn had to be put as the input, especially on the material testing for $\mathrm{C} 1, \mathrm{C} 4, \mathrm{C} 9$, and $\mathrm{C} 10$.

\section{Conclusion}

In modifying the iodized spray device, we compared the water brush spray to several energy resources using a compressor. On tested-device stage 1 , the test was conducted 5 times with the salt weight of 120 kilograms, and on the second stage, the salt weight was 100 kilograms with 5 times of test, so the total amount of salt used was $\pm 1,1$ tons. The preliminary and final settings showed that there was significant changes on the result, so it was crucial to set the pressure on the compressor. In addition, nozzle setting that showed the height of the nozzle on screw cycle on iodized machine needed to be reset because the holes of the nozzle was impacted by the iodized machine screw cycles when the iodine was mixed. The result of the trial as the first start salt machine was the Po (output) must be set back to the input, and the Pn (final result) must be set back.

The support comes from the Higher Education Board for the Implementation of Multi years of Reward Program and the decentralisation of Research Scheme on Applied Product of Higher Education for the batch of 2017 No. Ex.B/09/UHT.C7/V/2017 on May 4, 2017.

\section{References}

1. Komari et all, The Journal of Nutrition and food Research,(1995)

2. Pusriswilnon BRKP, The Guidance Book: The Integrated Development of Salt and Artemia. The Research Centre of Sea and Resources. The Board of Oceanography and Fishery. The Department of Oceanography and Fishery(2006).

3. Sulistyowati et al, "Optimizing the Usage of Salt Fortification Result Mechanically and Chemically to have Iodized Salt ", Neptunus 19 no 1, ISSN. 0852-2812.(2013)

4. Utama. Rusda H, Oenzil F, Alioes Y, Journal of health andalas, 2 : 85-89 (2013).

5. Bagiyo Suwasono, Ali Munazid, Giman Hilmawan and Budtomo, Design of Salt Fortification Mechanically and Chemically. Cooperation between Partners and KKP, Jakarta. UHT Surabaya and Oceanography Vocational School SunanDrajat, Lamongan.(2010)

6. Amarullah, Husni and Sriyanto, Technology on Artemia Salt and Other Related Products. BPPT, Paper on a Workshop: The Future of Salt Industry in Indonesia. (2006).

7. Almatsier, Sunita, Basic Principle of Nutrition., Jakarta PT. Gramedia Pustaka (2003).

8. Ruwhof $\mathrm{C}$ and Drexhage $\mathrm{HA}$, .Iodine and thyroid autoimmun diseasein animal models. Thyroid 11:427-36, (2001).

9. Anonymous, 1993, Sodium Chloride in Chemieal Index.

10. KerryMgruder, ,Halite, Guidelines forRoek Collection. (2000)

11. Bisnis Indonesia. World Bank Gives Funds to 20 Salt Companies for SNI Processes, (2000)

12. Bisnis Indonesia. Salt Farming Needs Technology Standard, (2000) 
13. Fitriana, R. South Coast of Central Java Have Potential of Salt. Bisnis Indonesia, (2000)

14. Guidance Book of Iodized Salt. 2010. Salt Company, PT. Apel Merah, Rembang.

15. PT. Garam, The Technology of the Making and the Problems of Salt Production. The Department of Marine and Fishery.. (2000).

16. Rilleyand Skirrow, Chemieal Oceanography, Academie Press London, (1975) 